IZA DP No. 6598

Employment Effects of State Legislation against the Hiring of Unauthorized Immigrant Workers

Sarah Bohn

Magnus Lofstrom

May 2012 


\title{
Employment Effects of State Legislation against the Hiring of Unauthorized Immigrant Workers
}

\author{
Sarah Bohn \\ Public Policy Institute of California \\ Magnus Lofstrom \\ Public Policy Institute of California \\ and IZA \\ Discussion Paper No. 6598 \\ May 2012 \\ IZA \\ P.O. Box 7240 \\ 53072 Bonn \\ Germany \\ Phone: +49-228-3894-0 \\ Fax: +49-228-3894-180 \\ E-mail: iza@iza.org
}

Any opinions expressed here are those of the author(s) and not those of IZA. Research published in this series may include views on policy, but the institute itself takes no institutional policy positions.

The Institute for the Study of Labor (IZA) in Bonn is a local and virtual international research center and a place of communication between science, politics and business. IZA is an independent nonprofit organization supported by Deutsche Post Foundation. The center is associated with the University of Bonn and offers a stimulating research environment through its international network, workshops and conferences, data service, project support, research visits and doctoral program. IZA engages in (i) original and internationally competitive research in all fields of labor economics, (ii) development of policy concepts, and (iii) dissemination of research results and concepts to the interested public.

IZA Discussion Papers often represent preliminary work and are circulated to encourage discussion. Citation of such a paper should account for its provisional character. A revised version may be available directly from the author. 


\title{
ABSTRACT
}

\section{Employment Effects of State Legislation against the Hiring of Unauthorized Immigrant Workers*}

\begin{abstract}
We analyze the impact of the 2007 Legal Arizona Workers Act (LAWA) on employment outcomes of low-skilled Arizona workers, with a focus on the states' unauthorized population. The intent of LAWA was to limit unauthorized workers' economic opportunities as a way to deter further illegal immigration and as such is likely to increase poverty among an already marginalized population. Specifically, we assess whether the legislation reduced the formal employment opportunities of the targeted population. We also look for evidence of an unintended consequence of the policy: whether LAWA pushed workers into informal employment, and if so what are the likely consequences for these workers and their families. Using the synthetic control method developed by Abadie, Diamond and Hainmueller (2010), we find no statistically significant pre-post LAWA differences in wage and salary employment rate for the vast majority of workers in Arizona. Only among the workers most likely to be unauthorized - non-citizen Hispanic men with at most a high school education - do we observe a statistically significant relative decline in the probability of wage and salary employment. We also identify a substantial and statistically significant relative increase in the rate of self-employment among the same group of likely unauthorized workers, and not among other groups. Our data suggests that this shift is likely associated with an increase in poverty among unauthorized immigrants.
\end{abstract}

JEL Classification: J8, J11, J15, J18, J48, J61

Keywords: $\quad$ illegal, unauthorized, undocumented, immigration, Hispanic, Arizona

Corresponding author:

Magnus Lofstrom

Public Policy Institute of California (PPIC)

500 Washington Street, Suite 600

San Francisco, CA 94111

USA

E-mail: lofstrom@ppic.org

\footnotetext{
* We gratefully acknowledge the support of the Russell Sage Foundation. We also like to thank the editors, Judith Gans, Hans Johnson, Heather Koball, Ethan Lewis, Fernando Lozano, Albert Liu, Jordan Matsudaira, Marie Mora, David Neumark, Pia Orrenius, Jeffrey Passel, Karthick Ramakrishnan, Marc Rosenblum, and participants at the San Francisco Federal Reserve Bank's 2010 Applied Micro Conference, the Population Association of America's 2011, the American Economic Association's 2012 Annual Meeting, the Immigration and Poverty Conference at UC Davis for helpful feedback and seminar participants at UC Irvine, UC Merced and the University of Otago.
} 


\section{Introduction}

The U.S. is home to a large and growing number of unauthorized immigrants. The most recent estimates indicate that this population increased from about 3 million in the late 1980s to around 11 million in 2009 (Passel and Cohn, 2010). Not surprisingly, the size and growth of the unauthorized immigrant population has not gone unnoticed and is the source of much controversy surrounding immigration policy. Reflected in both the recent efforts to reform the country’s immigration policy and the last major immigration reform, the 1986 Immigration Reform and Control Act (IRCA), policymakers recognize that employment is the primary draw for most unauthorized immigrants. Instituting employer sanctions for hiring unauthorized immigrants was a key component of IRCA. However, the sanctions were little enforced and the lure of jobs and higher wages continue to attract numerous immigrants in spite of lacking legal rights to work in the US.

Despite several attempts at immigration reform, Congress has not been able to pass either comprehensive or piecemeal immigration legislation addressing illegal immigration. Reform efforts failed in 2006 and 2007, and its failure to pass the Dream Act in 2010 was the most recent example of Congressional gridlock on immigration. In the absence of federal legislative action states have increasingly taken it upon themselves to address the issue of illegal immigration. This recent trend is evident by the increase from 38 immigration-related pieces of legislation passed by state legislatures in 2005 to 346 such bills passed in 2010. Although these bills cover a wide range of issues many - 118 laws in 37 states between 2005 and 2010 - directly target the employment opportunities of unauthorized immigrants. 
Arizona is the state leading the charge against illegal immigration. Years before passing the highly publicized and controversial Senate Bill 1070 in April 2010, Arizona introduced legislation targeting employers hiring unauthorized immigrants. ${ }^{1}$ The Legal Arizona Worker Act (LAWA) was passed in July 2007 and implemented in January 2008. Although the law includes state imposed employer sanctions against firms knowingly hiring unauthorized workers business licenses suspension and possible revocation for repeat offenders - the arguably most important feature is the requirement that all employers use the federal E-Verify online work authorization system for all new hires. A number of states have since implemented similar mandates (Utah, South Carolina, Mississippi, and Oklahoma) and other states have proposed or discussed similar measures. Arizona provides an important test case for understanding the impacts of state legislation on employment of unauthorized immigrants. The likelihood of other states following the example of Arizona is even more likely given the May 2011 U.S. Supreme Court decision upholding the legality of LAWA.

Very little is known about the impacts of these laws but previous research shows that LAWA induced sizeable responses among the unauthorized population. Bohn, Lofstrom and Raphael (2011) find that the population of non-citizen Hispanic immigrants in Arizona - a high proportion of whom are unauthorized immigrants -fell by roughly 92,000 persons due to LAWA. This represents a roughly 17 percent decline in the likely unauthorized population in Arizona due to LAWA. This population shift came about through a combination of outmigration from Arizona to other states and abroad as well as a slowing of the inflow of new unauthorized immigrants to the state.

\footnotetext{
${ }^{1}$ SB 1070 targets unauthorized immigrants directly, as opposed to employers, and criminalizes failure to carry immigration documents and give the police broad power to detain anyone suspected of being in the country illegally. The constitutionality of the law is in question and prior to enactment a federal judge issued an injunction blocking the most controversial provisions, including the one requiring police to check individual's immigration status while enforcing other laws if there was reason to believe the person was in the country illegally.
} 
The intent of policies like LAWA is to limit unauthorized workers’ economic opportunities as a way to deter further illegal immigration and as such are likely to increase poverty among an already marginalized population. Hence, in this paper we address the important question of how those unauthorized immigrants who chose to stay in - or chose to come to - Arizona are affected by LAWA. Specifically, we analyze LAWA's impact on labor market opportunities of unauthorized workers in Arizona. We assess whether the legislation reduced their employment opportunities in formal employment (i.e. the wage and salary sector). Importantly, we also look for evidence of an unintended consequence of the policy: whether LAWA pushed workers into informal employment, and if so what are the likely consequences for these workers and their families. An increase in informal employment is clearly not the objective of the policy as the shift may be associated with lower income tax revenues due to both lower earnings and fewer workers contributing to the tax system. For workers pushed into informal employment, the effects are likely to be fewer benefits, lower wages, and potential for worsened working conditions. To estimate any shifts into informal employment, we obtain estimates of LAWA's impact on the self-employment rate in Arizona.

This chapter proceeds with brief description of LAWA and E-Verify in section 2 followed by a theoretical discussion in section 3. Then, we set forth our empirical approach and data in section 4, including discussion of the coincidence of the Great Recession and LAWA. Section 5 presents our empirical results. Section 6 discusses what the estimated labor market shifts mean for the economic well-being of immigrants, and Section 7 concludes.

\section{State-Level Immigration Legislation}

The increased efforts by states to address employment of unauthorized immigrants—an issue historically in the federal domain — represent an important shift in national immigration 
policy. State laws vary greatly in their restrictiveness and implementation of laws related to employment of unauthorized immigrants. Most of the comprehensive laws mandate use of EVerify.

\section{E-Verify}

E-Verify is an online system created and managed by the federal government to provide information to employers about whether an individual is authorized to work in the United States. E-Verify is intended to verify workers' Form I-9 information against Social Security Administration (SSA) and Citizenship and Immigration Services (USCIS) databases. E-Verify completes two verification tasks: authentication of identity and verification of work authorization. The system functions for all workers, citizens and non-citizens, and is intended for authorizing new hires only. Employers are not permitted to use E-Verify to check authorization of individuals until they have been hired and submit an I-9.

The federal government does not require employers to use E-Verify, except for firms with certain federal government contracts (administrative order instituted September 8, 2009). EVerify provides fast results, if identity and work authorization are confirmed—which, according to Westat (2009), occurs about 95 percent of the time. When confirmation is not granted (“tentative non confirmation” or TNC), the employee may appeal. While a TNC is being contested, employers are not allowed to dismiss the worker solely on the basis of the record. If an employee fails to or is unable to correct his or her TNC, after a relatively short period of time employers must terminate the employee.

The main problems with E-Verify are delays in correcting tentative non-confirmations, erroneous confirmations, and insufficient capacity as more employers enroll. Intensive 
refinement of the system in recent years has led to a decline in E-Verify error rates. For authorized workers, the accuracy rate of E-Verify is at least 99 percent, and unlikely to get much better. For unauthorized workers the error rate may be as much as 54 percent (Westat 2009). The costs - primarily time and energy - of correcting errors fall on the new hires as well as on local DHS and SSA offices where individuals must go to correct errors. Verification can be circumvented through employers avoiding using the system or through identity theft and falsifying documents by applicants. Thus, federal law and current state law supplement verification tools with enforcement.

The results of E-Verify at this time are not reported to any agency responsible for immigration enforcement. That is, even if a new hire is found to be unauthorized, these results are not transmitted to DHS or ICE for investigation, detainment, or deportation of the individual.

\section{Existing State Laws}

Colorado was the first state to pass legislation intended to reduce the hiring of unauthorized workers. Colorado's law requires any person or entity that has entered into a public contract with the state on or after August 2006 to certify that it has verified the legal status of all new hires using the E-Verify program. Similar laws or executive orders were enacted in Georgia in 2007, Rhode Island and Minnesota in 2008, Missouri and Utah in 2009. South Carolina, Utah, and Mississippi have recently passed legislation that phases in E-Verify use according to business size. In South Carolina, employers of all sizes were required to use E-Verify by July 2010. In Mississippi, all employers are legislated to be phased in by July 2011. The penalties for hiring unauthorized workers are stringent under the Mississippi law, and include loss of public contracts and suspension of business licenses. Utah's mandate covers all employers with 15 or 
more employees as of July 2010. Oklahoma constitutes a special case. While the first phase of the legislation was scheduled to go into effect in November 2007, a court challenge has held up implementation. To date, Oklahoma has yet to implement the provisions of its bill.

\section{The 2007 Legal Arizona Workers Act}

Arizona’s Legal Arizona Workers’ Act (LAWA) - signed into law in July 2007 and effective January 1, 2008 - imposes sanctions on employers who “knowingly” hire unauthorized immigrants: a business license suspension for the first offense and license revocation upon a second. LAWA is unique among recent state legislation on the employment of unauthorized immigrants in that it covers all firms, not just public agencies or those with state government contracts. It also mandates that all employers located in the state use E-Verify. Its broad range makes LAWA a good example of state legislation that mimics recent federal reform proposals. Importantly, Arizona is also the only place where all employers have been required to use EVerify for a sufficient period of time to allow for a reliable empirical evaluation.

Although the legislation has faced a number of legal challenges, it has been upheld by the federal district and appellate courts. The challenges to LAWA focus on the right of states to legislate on immigration enforcement. The U.S. Supreme Court heard arguments in the case, Chamber of Commerce et al v Whiting, in December 2010 and ruled in favor of the legislation in May 2011. The clearing of the constitutionality hurdle may spur additional interest in passing such laws.

We expect that LAWA's impacts to-date largely stem from a deterrent or compliance effect prompted by the E-Verify mandate rather than from employer sanctioning. Despite the sanctions established in LAWA, to date few have been assessed. Through April 2010, more than 
two full years following LAWA's enactment, only 3 prosecutions had been pursued, and all in a single county (Maricopa). Few sanctions may reflect the lack of resources in the County Attorney offices responsible for investigating claims. Or, few sanctions may reflect high compliance among employers. Indeed, statistics from the E-Verify system indicate growth in number of firms enrolled: from 300 in March 2007 in Arizona, to 38,000 in January 2010 (Westat (2009), Arizona Attorney General’s Office (2010)). Arizona firm enrollment represents roughly one-third of all firms enrolled nationwide. Further, estimates suggest that roughly 700,000 new hires made between October 2008 and September 2009 were run through E-Verify in Arizona (Arizona Republic (2010)). This correlates to roughly 50\% of all new hires in the state.

\section{The Effect of State-Level Immigration Legislation on State Labor Markets: Theoretical Predictions}

The intention of Arizona's LAWA is to deter the hiring of unauthorized immigrant workers by making it more expensive for employers to do so while simultaneously making Arizona less attractive to both the existing and potential future unauthorized immigrants. A motivation behind such legislation is to improve labor market opportunities for those legally eligible to work in the U.S. Whether such legislation is effective in this regard depends in large part on the degree to which authorized and unauthorized workers compete with one another in the labor market. This in turn is likely to vary by skill, nativity, ethnicity, gender, and the interaction of these dimensions.

To the extent that employers can distinguish unauthorized workers from documented workers, state laws punishing employers who hire the unauthorized can be modeled as increasing 
the relative costs of hiring unauthorized workers. Standard labor demand theory predicts that this would induce two reinforcing effects on the demand for unauthorized immigrants and two offsetting effects on demand for other workers. Regarding the targeted workers, higher costs of hiring unauthorized workers should induce both employer substitution towards other workers as well as a general reduction in employment associated with the higher compliance costs (e.g., the costs of additional verification requirements, the expected value of the penalty if caught). These substitution and scale effects should unambiguously reduce demand for unauthorized workers, lowering employment levels and perhaps average wages.

However, theory does not yield an unambiguous prediction for other groups of workers. To the extent that authorized immigrants and specific groups of the native-born are easily substitutable in production for unauthorized immigrants, employer substitution will boost labor demand for such workers and ultimately impact their average employment and earnings. However, the size of this substitution effect will be smallest for those who are the least like the unauthorized. In fact, there are certain labor groups that are likely to be complementary in production with unauthorized labor, implying that irrespective of the scale of production in the economy, an increase in the cost of hiring unauthorized workers would actually harm these natives.

For all authorized workers, even those that are close substitutes for the unauthorized, higher compliance costs may result in a reduction in the overall scale of an organization's activities. Hence, offsetting substitution and scale effects do not permit prediction of the impact of these laws on documented immigrants and the native born. Theory does suggest however, that with perfect information on legal status those authorized workers most similar in skill to the unauthorized stand to gain the most. 
When employers cannot easily distinguish the documented from the unauthorized, the potential impacts of such state legislation are complicated by the likelihood that employers form probabilistic assessments of the legal status of specific applicants and then act on those assessments. Specifically, if employers cannot tell with certainty who is and who is not authorized, employers may infer legal status through such visible signals as ethnicity, accent, or surname.

Note that even an accurate verification system may lead some employers to avoid hiring individuals from these groups since authorization through E-Verify is not checked until after the individual has been hired. In the event of an accurate non-confirmation of work authorization, the new hire has a period of time in which to correct the finding through DHS or SSA (this is the new hire's responsibility and not the employers). During this period the employer cannot fire the employee except for issues unrelated to his or her work authorization status. The employer may then lose productivity of the new hire during the waiting period and incur additional hiring costs. In Arizona, Hispanic or foreign-born applicants, in particular those with less education, are most likely to be negatively impacted by this potential employer behavior.

Lastly, LAWA's E-Verify mandate applies to all employers, for all new employees. However, it includes only licensed business in the definition of employers. LAWA also specifically excludes independent contractors from the definition of an employee. Thus, one way to avoid use of E-Verify is to enter into an independent contractor arrangement instead of formal wage/salary employment. It is possible that workers would maintain the same work activities and employer but shift the relationship from being a wage worker to a contractor, for example. It is hence important to also study whether LAWA induced unauthorized immigrants who remained in Arizona to rely on self-employment, or informal employment, to a greater 
extent as a consequence of LAWA and how this affected their own and their families' economic well-being. There is wide variety in what informal or self-employment would mean for unauthorized workers in Arizona. Beyond independent contracting, other common examples of self-employment among unauthorized workers may also pertain, for example, day laborers and micro-entrepreneurs, work typically associated with the informal labor market.

A shift towards work in the informal sector is of greatest concern for the targeted population: unauthorized immigrants. Unauthorized immigrants who choose to live in Arizona are likely to have more limited opportunities for employment, particularly in the formal sector. Shifting to informal work has economic consequences for workers due to lower earnings and potential exploitation as well as to the economy more broadly due to lower tax revenue. The Congressional Budget Office, in assessing the cost of E-Verify, estimates that a US-wide mandate would decrease revenue $\$ 17.3$ billion over 9 years as a result of unauthorized workers shifting to being paid outside of the tax system.

Because LAWA only applies to Arizona, workers have the option of migrating elsewhere where obtaining a job in the formal sector is easier. However, the more states that enact employment enforcement legislation, the fewer the options for unauthorized immigrants and thus the larger the potential growth in informal employment. This concern is particularly salient when employment enforcement laws are enacted on a piecemeal state-by-state basis and without reform to the other aspects of immigration policy. We discuss these issues in more detail below.

\section{Data and Empirical Strategy}

To assess the employment effects of LAWA, we analyze data from all monthly Current Population Survey (CPS) data sets collected between January 1998 and December 2009. These 
data provide details on the employment of individuals in each state as well as information on race/ethnicity, education, age, and other demographic characteristics including immigration status (native-US born or foreign- born naturalized citizen, or not a citizen). Our analysis primarily focuses on the impacts on the population targeted by LAWA: unauthorized immigrants. Ideally, we would like to directly examine outcomes of unauthorized workers in Arizona. But neither these CPS data, nor any suitable available data allow for precise identification of unauthorized immigrants at the individual level. Nonetheless, among certain population groups that we can identify in the data, the likelihood of being unauthorized is substantially elevated. In particular, by definition there should be no unauthorized immigrants among those who report being "naturalized immigrant” or U.S. born. Further, unauthorized immigrants are more likely to be men, of working age of Hispanic origin, and have fewer years of formal education (Passel and Cohn, 2010).

Thus for our analysis we examine outcomes for the following demographic groups that have varying proportions of unauthorized immigrants:

- $\quad$ Foreign-born non-citizen Hispanics

- Foreign-born naturalized citizen Hispanics

- $\quad$ Native-born Hispanics

- Native-born non-Hispanic whites

We estimate that in Arizona upwards of 80 to 90 percent of the first group, foreign-born noncitizen Hispanics, are unauthorized. ${ }^{2}$ The second group should have no unauthorized immigrants

\footnotetext{
${ }^{2}$ For example, our calculations from Census data indicate roughly 517,000 non-citizen Hispanic immigrants resided in Arizona in 2008. For this same year, Passel and Cohn (2009) estimate that there were 475,000 unauthorized immigrants in the state. Similarly, for our finer definition of likely unauthorized workers used in the traditional difference-in-difference approach, based on ACS data, we estimate 229,000 likely unauthorized in Arizona in 2008
} 
assuming no reporting error. And the last two groups, both native-born, should also by definition have no unauthorized immigrants. Given that unauthorized immigrants are more likely to be men and have lower levels of educational attainment, much of the focus is on men with high school degrees or less.

In order to obtain large enough samples of these relatively small demographic groups, we combine monthly CPS files within years and estimate employment outcomes on an annual basis, from 1998-2009. The CPS data, nor any other comprehensive data source, do not yet allow for robust analysis of wages through 2009. The CPS data, though relatively current, do not have large enough samples in our narrowly defined demographic groups. Larger samples are available in the American Community Survey, but currently these data only report wages through 2008. Thus, we focus in this paper on examining employment rather than wages. We estimate impacts on two primary and mutually exclusive outcomes: employment in wage and salary work and self-employment.

In order to identify the causal impact of LAWA on employment outcomes in Arizona, we employ the synthetic control approach of Abadie, Diamond and Hainmueller (2010). Key to the identification strategy is charting the appropriate counterfactual path for Arizona in absence of LAWA. There are a number of approaches one could employ. One is to select states that share similar population and economic characteristics and trends as Arizona; for example, the states bordering Arizona (a traditional difference-in-difference approach). Another would be to employ a data-driven search for comparison states based on pre-LAWA population and employment characteristics and trends (the synthetic control method of Abadie et al (2010)). We use both, but focus on the latter, because it is arguably the most reliable and essentially incorporates the first

whereas Passel and Cohn (2009) estimate 240,000 unauthorized immigrants in Arizona's labor force in the same year. 
strategy. It allows the data to tell us which states best match Arizona's pre-LAWA experience. We also implement the alternative strategy of using only neighboring areas (Nevada, New Mexico, Utah, and inland California). This approach, utilizing ACS data, generates very similar results to those presented in the report and results are available upon request.

The synthetic control method allows for robust analysis in the single policy change single state context. We summarize the methodology for charting a counterfactual post-LAWA path for Arizona here. The basic idea is to generate a comparison group from a convex combination of states in a large donor pool. Let the index $\mathrm{j}=(0,1, \ldots, \mathrm{J})$ denote states. The value $\mathrm{j}=0$ corresponds to Arizona and $\mathrm{j}=(1, \ldots, \mathrm{J})$ correspond to each of the other $\mathrm{J}$ states that are candidate contributors to the control group (or in the language of Abadie et. al, the donor pool). Define $F_{0}$ as a $9 x 1$ vector with elements equal to the group-specific employment outcome in Arizona in years 1998 through 2006 (the nine years we use throughout this paper as our preintervention period). Similarly, define the $9 \mathrm{xJ}$ matrix $F_{1}$ as the collection of comparable time series for each of the J states in the donor pool (with each column corresponding to a separate state-level time series for the period 1998 through 2006).

The synthetic control method identifies a convex combination of the $\mathrm{J}$ states in the donor pool that best approximates the pre-intervention time series for the treated state. Define the Jx1 weighting vector $W=\left(w_{1}, w_{2}, \ldots, w_{J}\right)^{\prime}$ such that $\sum_{j=1}^{J} w_{j}=1$, and $w_{j} \geq 0$ for $\mathrm{j}=(1, \ldots, \mathrm{J})$. The product $F_{1} W$ then gives a weighted average of the pre-intervention time series for all states omitting Arizona, with the difference between Arizona and this average given by $F_{0}-F_{1} W$. The synthetic control method essentially chooses a value for the weighting vector, $W$, that yields a synthetic comparison group (consisting of an average of some subset of donor states) that best 
approximates the pre-intervention path for Arizona. Specifically, the weighting vector is chosen by solving the constrained quadratic minimization problem

$$
\begin{aligned}
& W^{*}=\underset{W}{\arg \min }\left(F_{0}-F_{1} W\right)^{\prime} V\left(F_{0}-F_{1} W\right) \\
& \text { s.t. } \\
& W^{\prime} i=1, w_{j} \geq 0, j=(1, \ldots J)
\end{aligned}
$$

where $V$ is a 9x9, diagonal positive-definite matrix with diagonal elements providing the relative weights for the contribution of the square of the elements in the vector $F_{0}-F_{1} W$ to the objective function being minimized.

Once an optimal weighting vector $W^{*}$ is chosen, both the pre-intervention path as well as the post-intervention values for the dependent variable in "synthetic Arizona" can be tabulated by calculating the corresponding weighted average for each year using the donor states with positive weights. The post-intervention values for the synthetic control group serve as our counterfactual outcomes for Arizona.

Our principal estimate of the impacts of LAWA on employment outcomes uses the synthetic control group to calculate a simple difference-in-differences estimate. Specifically, define Outcome ${ }_{\text {pre }}^{A Z}$ as the average value of the outcome of interest for Arizona for the pre-intervention period 1998 through 2006 and Outcome ${ }_{\text {post }}^{A Z}$ as the corresponding average for the two posttreatment years 2008 and 2009. Define the similar averages Outcome $e_{\text {pre }}^{A Z}$ and Outcome $e_{\text {post }}^{A Z}$ for the synthetic control group. Our difference-in-differences estimate subtracts the pre-intervention difference between the averages for Arizona and synthetic Arizona from the comparable postintervention difference, or

$$
D D_{A Z}=\left(\text { Outcome }_{\text {post }}^{A Z}-\text { Outcome }_{\text {post }}^{\text {syth }}\right)-\left(\text { Outcome }_{\text {pre }}^{A Z}-\text { Outcome }_{\text {pre }}^{\text {synth }}\right)
$$


To formally test the significance of any observed relative decline in Arizona's foreign-born population, we apply the permutation test suggested by Abadie et. al. (2010) to the difference-indifference estimator displaced in equation (2). ${ }^{3}$ Specifically, for each state in the donor pool, we identify synthetic comparison groups based on the solution to the quadratic minimization problem in equation (1). We then estimate the difference-in-difference in (2) for each state as if these states had passed the equivalent of a LAWA with comparable timing. The distribution of these "placebo" difference-in-difference estimates then provides the equivalent of a sampling distribution for the estimate $D D_{A Z}$. To be specific, if the cumulative density function of the complete set of $D D$ estimates is given by $F($.$) , the p-value from a one-tailed test of the$ hypothesis that $D D_{A Z}<0$ is given by $F\left(D D_{A Z}\right)$.

To interpret $D D_{A Z}$ as a causal estimate of LAWA's employment effects, we must make the case that LAWA represents an exogenous shock to the labor market. For example, if high unemployment among the foreign born and the attendant problems led Arizona to enact legislation to discourage future migration to the state, inference on $D D_{A Z}$ would be compromised. In fact, LAWA was debated and passed during a period of economic growth but was enacted at a time of declining labor market conditions in Arizona. A number of facts suggest that the passage and enactment of LAWA was not driven by employment conditions in the state at the time but instead reflected Arizona’s perceived long-term problem of unauthorized immigration, also experienced by other states. To start, LAWA represents the ultimate manifestation of a fairly lengthy legislative debate that crossed multiple legislation sessions. Moreover, there was considerable uncertainty as to whether LAWA would be enacted on January

\footnotetext{
${ }^{3}$ Buchmueller, DiNardo and Valletta (2009) use a similar permutation test to that described here to test for an impact of Hawaii's employer-mandate to provide health insurance benefits to employees on benefits coverage, health care costs, wages and employment.
} 
1, 2008. Federal lawsuits challenging the constitutionality of LAWA were brought by an alliance of civil rights advocates, business interests and immigrant rights groups. The challenge was dismissed, but not until early December. Anecdotal evidence suggests that those likely to be affected by actual implementation followed the court challenge and were conditioning their responses on the ultimate legal outcome (see The Arizona Republic, October 8, 2007).

A further challenge to causal interpretation of $D D_{A Z}$ is potential coincident timing of other changes in Arizona's labor market that could work in the same direction as LAWA. Although LAWA has the potential to impact the labor market, a number of other forces also drive those conditions. Under the synthetic control approach, unless the timing of these other forces was exactly coincident with that of LAWA, we argue that our estimates represent the causal relationship between LAWA and Arizona's employment outcomes. This argument hinges on the ability of the synthetic control method to (1) match Arizona’s pre-LAWA trends with those of other states and (2) determine whether Arizona's pre-post changes stand out from the placebo estimates for all other states. We will show in the following section that both of these conditions are satisfied. Given that, we need only address the two major factors coincident with LAWA that could potentially invalidate the claim of causality.

First, we are concerned about the potential coincidence of federal immigration enforcement increases with the enactment of LAWA. We have reviewed DHS data and have found nothing to suggest that federal enforcement increases at the border or in internal investigations happened differentially in Arizona than in other border states and/or happened at exactly the same time. The Arizona Border Control Initiative, which built up infrastructure on Arizona’s border with Mexico predated LAWA by a few years. Further, our review of DHS arrest and apprehension data suggests that a similar percentage of all border apprehensions occurred in the Tuscon sector 
(about 42\%) following LAWA and the number of arrests resulting from ICE investigations actually fell (Office of Immigration Statistics, 2010).

Second, the "Great Recession" occurred at approximately the same time of the enactment of LAWA. There is evidence that the recession reduced the inflow of new immigrants to the US and new immigrants to Arizona. Our empirical approach comparing trends in Arizona to other states already accounts for any changes that affect the country as a whole (or the selected comparison states). However, one of the industries hit hardest, construction, is a leading employers of unauthorized immigrants. Furthermore, construction is one of the biggest industries in Arizona (representing close to 11 percent of total private employment in 2006) so the state's economy can be impacted significantly by declines therein. Thus, it is important in our evaluation strategy to ensure that we do not attribute changes in population to LAWA if they were in fact driven by the decline in construction and real estate in Arizona specifically. To validate our empirical approach, we assess official statistics on employment trends in Arizona and neighboring states during the recession.

The recent recession caused a clear reduction in Arizona's workforce. Figure 1 shows strong employment growth 2003-2006 with a noticeable slow down in 2007. This was followed by three and eight percent decreases in 2008 and 2009, respectively. Figure 1 also shows that the negative employment effects of the recession on employment were not any stronger in Arizona than it was in neighboring areas, including inland California (an area that shares many of the characteristics and trends of Arizona, is hence used in our empirical analysis). Lastly, an application of the synthetic cohort method to employment growth fails to reveal a LAWA effect in Arizona. 
Importantly, the recession was precipitated by a housing crisis, which brought new housing construction to a near standstill. The fact that many unauthorized immigrants are, or maybe more accurately were, employed in the construction sector means that they may have been particularly affected by the recession. However, a look at construction employment data reveals no evidence that Arizona's construction industry fared much differently in the recession than its neighboring areas (Figure 2).

Overall, the data indicates that while Arizona's labor market was strongly affected by the recession, so were other states', including its neighbors. The similarity in trends indicates that our empirical strategy is appropriate for identifying causality despite the recent recession.

\section{Empirical Results - Did LAWA have any employment effects?}

We begin our analysis of whether LAWA affected employment opportunities of illegal immigrants in Arizona by examining employment rates (defined here as the ratio of persons employed in the wage and salary sector). As discussed above, for those workers who remained in Arizona following LAWA, a variety of employment effects is plausible. To the extent that firms are hiring and are in compliance with LAWA, unauthorized immigrants are less likely to find employment. There are potential spillover effects on other workers, in both positive and negative directions.

The data indicates that non-citizen Hispanics in Arizona experienced a particularly large post-LAWA drop in employment. Figure 3 shows that prior to the passing of LAWA in 2007, the employment rate of non-citizen Hispanics in wage and salary work was relatively stable around 60-63 percent: lower than non-Hispanic whites but similar to native and naturalized Hispanics. The data however show a different pattern in the post-LAWA period. The employment rate of 
non-citizen Hispanics in particular drops sharply in 2008 and by 2009 they have substantially lower employment rates than the other groups.

Because we want to focus on individuals who are likely to work, we next restrict our sample to 16 to 60 year old men. Furthermore, while we estimate outcomes for all groups, we pay particular attention to the group that contains the highest proportion of unauthorized workers: less educated workers, those with a high school diploma or less.

To probe the employment changes further, we apply the synthetic control approach and use the comparison states, which mimic Arizona’s 1998-2006 employment trend. In this exercise, we omit from the donor pool four states with broadly applied restrictions on the employment of unauthorized immigrants (Mississippi, Rhode Island, South Carolina, and Utah) even though the timing of their legislation post-dates LAWA. ${ }^{4}$ In addition, in identifying synthetic control states for placebo tests on each of the other states in the donor pool, we omit Arizona. Since unauthorized immigrants in Arizona experiences some of the sharpest drops in employment following LAWA, shown below, omitting Arizona from the donor pool for estimating the placebo intervention effects should impart a negative bias (a specification choice that should make it more difficult for us to find a significant effect).

The states receiving positive weights in the synthetic control for Arizona vary depending on the outcome variable and the subgroup analyzed. For example, for the wage and salary employment rate analysis among non-citizen Hispanics with a high school diploma or less, six states were assigned positive weights but two states combined for more than 90 percent of the weight, California (0.845) and New Mexico (0.077). For the same group in our analysis of the

\footnotetext{
${ }^{4}$ Moreover, the donor pool of states is further restricted for some of the smaller population subgroups due to the corresponding small CPS sample size.
} 
self-employment rate, nine states received positive weights with Massachusetts (0.42), Florida (0.143) and Tennessee (0.141) given the largest weights.

\section{LAWA Effects on Formal Employment}

Figure 4 shows that prior to the passing of LAWA, the wage and salary employment rates of non-citizen Hispanics matched those of non-citizens in the synthetic Arizona quite well. Average pre-intervention differences between Arizona and the synthetic control groups are near zero for each outcome, with quite small root mean squared errors. Hence, the synthetic control approach passes the first hurdle - succeeds in obtaining of convex combination of states that match Arizona's pre-LAWA trend. Beginning in 2007 we start to observe a divergent pattern. In the two post-LAWA years we observe the non-citizen Hispanic employment rate is between 11 and 12 percentage points lower than in the comparison states.

Average differences between Arizona and the synthetic control are calculated in the preLAWA period (1998-2006) and post-LAWA period (2008-2009). These and the difference-indifference estimate, $D D_{A Z}$, are presented in Table 1 (third row). Following LAWA, the employment rate of non-citizen Hispanic men with lower levels of educational attainment fell slightly more than 11 percentage points relative to the synthetic control. To obtain a p-value on $D D_{A Z}$ as well its non-parametric rank, we replicate the synthetic control method on each state in the donor pool and obtain a distribution of difference-in-difference estimates.

The set of difference-in-difference point estimates, $D D$, is used to calculate the p-value and rank of $D D_{A Z}$. These statistics are given in the last two columns of Table $1 .{ }^{5}$ We find that the

\footnotetext{
${ }^{5}$ Figure 5 graphically displays the raw data needed to conduct the permutation test of the significance of the relative declines in Arizona. Specifically, for each of the 40 donor states as well as for Arizona, the figures display the yearby-year difference between the outcome variable for the "treated" state and the outcome variable for the synthetic
} 
difference-in-difference estimate for Arizona stands out as a clear outlier in the distribution of placebo estimates. The 11.4 point decline is the largest among all states and is a statistically significant decline. Using the size of the non-citizen Hispanic population and workforce in Arizona in 2006 as the base (about 531,000 and 308,000 respectively), our estimates suggest that LAWA caused a drop in wage and salary employment of roughly 56,000 non-citizen Hispanic workers.

Panel A of Table 1 reveals that wage and salary employment declines among likely unauthorized workers in Arizona comes from (1) the less-educated and (2) males. This is driven, of course, by the fact that most unauthorized immigrants in the state are in these two subgroups. Note, however that we do not detect any statistically significant declines in wage and salary employment among likely unauthorized women due to LAWA.

The next three panels of Table 1 show that there is no evidence for impacts of LAWA on the competing groups of workers we examine. There are no statistically significant declines or improvements in wage and salary employment for less skilled naturalized Hispanics, native-born Hispanics or native-born whites. The full set of wage and salary employment results suggests that LAWA achieved its goal of reducing the employment of unauthorized immigrants in Arizona. There is no evidence of success towards the secondary goal of such legislation - to improve the employment opportunities for competing workers.

\section{LAWA Effects on Self- Employment}

Wage and salary employment tells only part of the story, however. LAWA's E-Verify mandate includes only licensed businesses within its employer definition, and also specifically

control. The differences for each of the donor states are displayed with the thin black lines while the differences for Arizona are displayed by the red thick line. 
excludes independent contractors from its definition of an employee. ${ }^{6}$ Thus, one way to avoid EVerify is to enter into independent contractor arrangements instead of formal wage and salary employment. Using self-employment as a proxy measure to potentially capture this effect, we next assess the impact of LAWA on self-employment among the likely unauthorized workers in Arizona and their substitutes.

The synthetic cohort results quite strongly suggest that Arizona's legislation substantially increased self-employment among non-citizen Hispanic immigrants. Figure 6 indicates that the self-employment rate among Hispanic non-citizen men was on the rise before LAWA in both Arizona and the comparison states. However, the rise between 2007 and 2009 is substantially greater in Arizona. The estimate of the magnitude of LAWA's self-employment effect is about 8 percentage points, roughly a doubling of the self-employment rate. Table 2 presents the point estimates of difference in pre- and post-LAWA for Arizona relative to the synthetic control. The difference-in-difference estimate suggests that the self-employment rate for likely unauthorized men in Arizona rose 8.3 percentage points higher relative to the synthetic control group.

Conducting the same placebo test on the set of self-employment rate outcomes yields similar conclusions. For likely unauthorized less-skilled men, the rise in self-employment rate is a clear outlier among all states. The 8.3 percentage point relative increase is statistically significant at the $5 \%$ level. Using the base of 308,000 workers in 2006, this translates to an increase of approximately 25,000 self-employed Hispanic non-citizens due to LAWA.

Among men of other ethnic and nativity groups, there is no evidence of statistically significant change in the self-employment rate due to LAWA. Similarly, among women we detect no statistically significant increases or decreases in self-employment due to LAWA.

\footnotetext{
${ }^{6}$ Regulations regarding business licensure vary by city and county. At the state level, the Arizona Department of Revenue does not require licensing of businesses that employ withholding-exempt employees only. This includes seasonal workers and domestic help. (Telephone communication with Arizona Department of Revenue 7/13/2010).
} 
In sum, these results suggest that among unauthorized men in Arizona, wage and salary employment opportunities became quite limited as a result of LAWA and many opted to shift their efforts to self-employment. These effects are concentrated among the group of less-skilled, likely unauthorized men and we find no convincing evidence of spillover effects to competing low-skilled groups.

In addition to the estimated decline in unauthorized population of roughly 90,000 persons (Bohn, Lofstrom and Raphael, 2011), for the unauthorized workers who chose to live in Arizona following LAWA, there were sizeable changes in employment opportunities. LAWA caused a decline of over 50,000 unauthorized workers in wage and salary jobs. This decline appears not to have had deleterious consequences - nor observable benefits - for competing workers. However, the unintended consequence of declining employment opportunities for unauthorized workers is a sizeable shift - about 25,000 people - into self-employment.

This set of findings raises the concern of a move into underground economies as an unintended consequence of legislation aimed at reducing the employment of unauthorized immigrant workers. In the following section we take the next step to look at what this shift into self-employment means for the economic well-being of unauthorized immigrants.

\section{Robustness Checks of Employments Effects}

We next explore the robustness of the estimated impacts of LAWA on formal and selfemployment. We focus on the group of with the highest proportion of unauthorized workers: non-citizen Hispanic men with no schooling beyond high school. This is the only group for which we obtain strong evidence of an impact of the legislation on employment. 
We begin by exploring the sensitivity of whether the year of the passage of legislation, 2007, is defined as a pre- or post-LAWA year. In all of the estimates that we have presented thus far we define the post-period as calendar years 2008 and 2009 due to the fact that LAWA was implemented on January 1, 2008. Furthermore, we have not matched the treatment to the synthetic controls with 2007 values and instead have omitted this year from our post-treatment period. Arguably, since the legislation was not in effect in 2007 and hence no hires were subject to the E-Verify mandate, this year should be included as a pre-LAWA year. The results when this is implemented, shown in the second rows in each of the panels in Table 3, reveal it has no real impact on the estimated effects of LAWA on either the wage/salary or self-employment rates (for ease of comparison, we repeat the corresponding Table 1 and 2 results in the top rows in each panel). On the other hand, one might contend that 2007 should be included as a posttreatment year as the legislation was passed mid-2007 and changes may have taken place in anticipation of the law's passage and implementation. We do find somewhat smaller effects (by about two percentage points) when 2007 is defined as a treatment year, shown in the third rows in the Table 3 panels. The rank test of this robustness check puts the estimated impacts in the upper tail of the placebo estimates but they do no longer stand out as the most extreme (for both outcomes the Arizona difference-in-difference estimates are $38^{\text {th }}$ in magnitude out of 40 states). However, we do not think it is appropriate to define 2007 as a treatment year since the anticipatory effects should plausibly be small: the mandatory use of E-verify does not commence until January 2008, there was uncertainty of whether the law would go into effect at that time, and since the enhanced verification requirement did not apply retroactively to past hires. Although the estimates are not very sensitive to how 2007 is handled, our preferred approach 
however is to only match on the 1998-2006 period and omit 2007 in the difference-in-difference calculations.

Our estimates may have been partially influenced by employment outcomes in the states comprising "synthetic Arizona", which may have been influenced by the influx of immigrants from Arizona. This might be a particularly important source of bias if migrants leave Arizona for neighboring states such as New Mexico and California since these contribute disproportionately to the synthetic control group for many of the employment outcomes we analyze and are also plausibly the most likely destination states for such migrants. To explore this we estimate our models restricting the donor pool to states that do not neighbor Arizona, results shown in the fourth rows in Table 3 panels. Both the estimated magnitudes and statistical significance are remarkably similar to those including neighboring states in the donor pool. This strongly suggests that our preferred estimates of LAWA's employment effects are not due to migration responses that alter employment outcomes in the neighboring states.

Migration could still bias our estimates, however, if it yields a compositional change in the targeted population that remains in Arizona following LAWA. In particular, we are concerned with skill characteristics that drive the employment outcomes we measure. To address this concern, we examine observable skill characteristics of the immigrant population in Arizona before and after LAWA and immigrants who left Arizona following LAWA. Because of small sample sizes in the CPS, for this exercise we utilize the American Community Survey for 20052010 and identify Hispanic noncitizen immigrants (finer subgroups are identifiable but sample sizes among migrants are unreliably small). We identify immigrants who left Arizona for another U.S. state in the post LAWA period, 2008-2009. ${ }^{7}$ Because the ACS inquires about migration in the year before the survey, for this "leaver" group, we observe outcomes and

\footnotetext{
${ }^{7}$ Note that one important group for whom we have no information is those who left Arizona for abroad.
} 
characteristics as of 2009-2010, which is not the same as the post-LAWA period used throughout this chapter. Thus, for comparison we provide statistics on the Arizona immigrant population in 2009-2010 and 2008-2009. As shown in Table 4, compared to those in Arizona, Hispanic noncitizens who left were slightly younger, more likely male and more likely to be a recent immigrant, consistent with typical migration patterns. There appears to be little compositional shift across these groups in terms of education, birthplace (Mexico), and marital status. Leavers are more likely to be proficient in English, which may suggest higher underlying skill. However, for those working, if there are differences in skill, they are not reflected in income differentials at the median. Employment outcomes are impacted by both LAWA, as we argue, and potentially by compositional changes in the immigrant population. ${ }^{8}$ However, we provide them here to show that Hispanic non-citizens who left Arizona were less likely to be employed, more likely unemployed, and much less likely to be self-employed than those in Arizona. Overall, but recognizing the limitations in the comparisons, the data do not indicate that those who left Arizona possessed more favorable labor market relevant characteristics. Also, given sample size constraints we view these results overall as suggestive that if anything a compositional change due to migration out of Arizona would bias us against finding an effect of LAWA.

We also explored a falsification test in which we imposed a false treatment in a preLAWA year. The selected year need to provide sufficient pre-treatment years to reliably identify appropriate synthetic control groups and allow for pre-LAWA time that is clearly not influenced by the legislation (and hence can serve as the fake treatment period). We choose 2004 since this matches these criteria and represents a year that potentially stood out in terms of employment

\footnotetext{
${ }^{8}$ In addition, employment opportunities for those remaining in Arizona may be improved due to an outflow of migrants following LAWA. This should bias against finding negative employment effects of the policy.
} 
outcomes, especially in construction employment (as Figure 2 indicates). The results, shown in row five in the panels in Table 3, fail to convincingly identify any noticeable effects in Arizona.

Lastly, we explore the sensitivity of the results stemming from the synthetic control method, which in order to obtain the most appropriate counterfactual for Arizona generates different state weights across the outcomes and sub-groups analyzed. That is, the composition of the synthetic control group varies with each outcomes and sub-group. Our approach here is to match on the total employment rate (wage/salary and self-employment rates) for non-citizen Hispanic men with high school or less. This will generate a set of state weights that we then apply equally to the wage/salary and self-employment rate time series. The task of repeating this exercise for all donor states is quite cumbersome to say the least and hence we do not have placebo estimates to compare the difference-in-difference estimates to. Our discussion instead focuses on the magnitudes of the estimated effects, shown in the bottom rows in the Table 3 panels. Not surprisingly, given that we do not utilize the combination of state weights yielded by the constrained minimization problem for the specific outcome and group at hand, the preLAWA differences between Arizona and the synthetic comparison groups are somewhat greater than those in the top row in each panel. However, the post-LAWA differences are quite similar in magnitude to those obtained when the matching is done based on the specific outcome in question. As a result, the estimated difference-in-differences are about one percentage point smaller, suggesting only a small sensitivity to utilizing a more uniform set of state weights based on overall employment.

Overall, the sensitivity analyses point towards robustness of our main results that LAWA severely limited formal employment opportunities for unauthorized immigrants and as a result many opted for more informal employment, as measured by the increase in self-employment. 


\section{What does the self-employment shift mean for unauthorized immigrants?}

A specific concern about a rise in self-employment is an associated growth in the underground labor market, also known as informal, shadow, under-the-table, or off-the-books employment. While clearly not all self-employment is underground work and not all underground work is recorded as self-employment, there is substantial overlap between the two. Both self-employment and informal employment raise concerns about economic consequences for workers as well as increased potential for exploitation. Furthermore, growth in self- and underground employment reduces government's ability to generate revenue through taxation. We first examine the literature on what informal employment likely means for unauthorized workers following LAWA, given that our data cannot inform this important question. Then we assess what the broader but overlapping arena of self-employment means from available data.

What is informal employment?

Informal work is difficult both to define and to measure, given that by nature underground work arrangements aim to avoid detection (Schneider and Enste, 2000). Informal work is most simply described as that which exists outside the legal boundaries set by local, state, or federal government (Feige, 1990; Flaming, Haydamack and Joassart, 2005). Informal work is thus not directly reported in official records or surveys. However, in our data, those who report self-employment are more likely to be in informal work arrangements than those who report wage and salary work, all else equal. In fact, some studies use self-employment as a proxy for informal labor (Flaming et al, 2005; De Soto, 1989). 
Our focus on unauthorized immigrants - or, in our data, non-citizen Hispanic men elevates the concern about a shift toward informal labor. Researchers have noted the ties between immigrants and informal work due to lack of documentation to work in the formal labor market, the incidence of underground economic activity in ethnic enclaves, and the fact that immigrants are over-represented in industries that also have higher probability of underground activity (Bohn and Owens, 2010; Marcelli, Pastor and Joassart, 1999; Light, 2006). For this reason, some researchers have used the concentration of unauthorized workers in an industry as a proxy for the informality of work (Marcelli et al, 1999).

Given that our population of interest - unauthorized workers - and an outcome of interest - self-employment - are both separately used in the literature as proxies for informal work, the unexpected rise in self-employment due to LAWA is inextricably tied to a likely rise in underground labor. To better understand what this means for unauthorized immigrants, then, is better understood by looking to the literature on informal work. We draw from a number of studies that detail the outcomes for informally employed immigrants in various cities.

Informal employment is linked in the public mind to day labor - especially immigrant day laborers - in large part because this type of informal employment is most noticeable. The most comprehensive study on day labor - the National Day Labor Survey - finds that a vast majority (79 percent) of day labor jobs are informal (Valenzuela, Theodore, Melendez and Gonzalez, 2006). However they represent a small fraction of informal employment. Using the NDLS for California only, one study finds that day labor represents only 3 percent of the undocumented workforce and only 0.2 percent of the total workforce (Gonzalez, 2007). However, this same study finds that Latino immigrants working as day laborers earn over $50 \%$ less per week than the average Latino immigrant and are less likely to find employment. As 
expected, the NDLS indicates that the top five occupations for day laborers are: construction laborer, gardener and landscaper, painter, roofer, and drywall installer.

Construction and landscaping industries are linked to informal employment of immigrants more broadly (Bohn and Owens, 2010; Flaming et al, 2005). The Flaming et al (2005) study of Los Angeles informal employment estimates that 10 percent of informal employment occurred in construction and 4 percent in landscaping services. A higher proportion of informal work can be attributed to manufacturing (20\%) and retail trade (15\%), as well as a high percent in private households (9\%) and accommodation and food services (6\%). The earnings for these estimated informal unauthorized workers are estimated at $\$ 16,553$ for men and $\$ 7,630$ for women in 1999, significantly lower than the Los Angeles median at that time of roughly $\$ 32,000$ for men and $\$ 30,000$ for women. ${ }^{9}$ Informally employed unauthorized immigrants in private households and landscaping earn among the lowest annual amounts, roughly around \$10,000 in 1999 .

The relatively low observed earnings for these unauthorized immigrants in informal jobs is of concern for their economic well-being and potential for economic assimilation. Bernhardt, McGrath and DeFilippis (2007) also identify cases of wage and hour violations on the part of employers in unregulated work arrangements. These violations also likely contribute to lower earnings, and include failure to pay minimum wage, overtime, or tips as well as full or partial non-payment of wages. In addition Bernhardt et al identify a host of other workplace violations that raise concern about workers employed informally. These include health and safety violations, lack of worker compensation coverage, discrimination, retaliation against the right to organize, and forced labor.

\footnotetext{
${ }^{9}$ source: U.S. Census Bureau Census 2000 Summary File 3
} 
Particularly relevant to our analysis of LAWA, Bernhardt et al (2007) identify abuse of independent contractor status. As we noted above, independent contractors are excluded from LAWA's E-Verify mandate. Thus one way to avoid detection is for a worker to shift into an independent contractor relationship with the employer. Bernhardt et al note that because independent contractors are not employees under the law, they are excluded from various wage and worker protections. They document a number of employer strategies to evade legal obligations by re-classifying workers as independent contractors. In their field study in New York City, they find that undocumented immigrants (and particularly recent arrivals) are at greatest risk to the host of workplace violations in informal work arrangements.

To our knowledge there is no detailed study of informally employed unauthorized immigrants in Arizona. However, we can learn from the case studies discussed here about the likely consequences for a shift to informal employment among non-citizen Hispanics in Arizona. This shift is likely to be correlated with constricted annual earnings, higher poverty rates as well as increased potential for numerous types of workplace violations.

What does a shift toward self-employment mean for unauthorized immigrants?

In an attempt to learn more about what self-employment means for the economic wellbeing and poverty of unauthorized immigrants, we generate descriptive statistics from the most recent, 2008 and 2009, American Community Survey. We restrict our sample to Hispanic immigrant men (non-citizen and naturalized) with a high school degree or less who reported being employed in the sample period. We do this since it is only among low-skilled non-citizen Hispanics we find statistically significant employment effects. While the ACS data provides the detail required for examining the income and poverty-related outcomes of self-employed likely unauthorized workers, the sample size and time period of analysis is limited. However, we use 
these data to describe what self-employment generally means for non-citizen Hispanics. Each survey reports on labor market outcomes for the preceding year; that is, the most recent outcomes we can examine are those pertaining to 2008. Indeed, this is what prevents us from using the ACS data in the empirical analysis of LAWA's effects presented earlier. Furthermore, the sample size of this subgroup in Arizona alone is quite small, so we look at the average outcomes for self-employed non-citizen Hispanics across the U.S.

Self-employment among non-citizen Hispanics is concentrated in a handful of industries. Table 5 reveals that two industries alone represent 2/3rds of the industries of self-employment: construction (46.6\%) and landscaping services (17.7\%). Rounding out the top five are automotive repair and maintenance (4.9\%), truck transportation (3.7\%) and restaurant and food services (3.1\%). The industry concentration is consistent with that of the informal sector discussed above and is not very surprising given the skill background of non-citizen Hispanic men as represented by their reported occupations. Table 5 also shows that construction laborers (14.2\%), carpenters (7.4\%) and painters (6.5\%) are three of the top five occupations. The other two are grounds maintenance workers (14.8\%) and drivers (4.6\%). Overall, the industry and occupational distributions are those that typify informal employment and the conditions and concerns of this sector plausibly apply to non-citizen Hispanic self-employment.

Table 6 reveals that there are only minor differences between our sample of non-citizen Hispanic men who are in self-employment and wage and salary employment. Those who report being self-employed are slightly older (38.4 and 35.5 years respectively for those in selfemployment and wage and salary employment) and have been in the US longer (15.5 and 13.2 years respectively) but are roughly equally likely to be high school graduates (30 and 31 percent), of limited English proficiency (82 and 84 percent respectively) and work roughly the 
same number of hours per week (39.6 and 40.7). There are some differences in household composition. The self-employed are more likely to be married (62 and 55 percent) and have more children on average (1.30 and 1.02). Overall, the differences are quite small and unlikely to be sources of substantial differences in economic well-being.

A comparison of income and benefits indicate lower economic well-being among those who report being self-employed compared to those in formal employment. Although mean annual earnings and income among those who report being self-employed is generally higher (the exception is total household income), the lower median annual earnings reveal that this is driven by a few self-employed who are relatively successful. The low median annual personal income of $\$ 18,000$ and annual family income of $\$ 30,000$ of those who report being selfemployed are about 10 percent lower than those in formal employment. ${ }^{10}$ The self-employed are also substantially more likely to have incomes below the poverty threshold: slightly more than $1 / 4$ of the self-employed (27 percent) compared to less than $1 / 5$ of their counter parts in wage and salary employment (18 percent). While only one out of three wage and salary workers in our sample has health insurance (32 percent), quite remarkably less than one out of five low-skilled non-citizen self-employed Hispanic men have health insurance (18 percent).

The ACS data provides a picture of self-employment consistent with the one gleaned from the informal employment literature reviewed above. This suggests that a rise in selfemployment due to LAWA is likely to be driven by a rise in underground employment. The literature and our data description indicate that unauthorized workers in less formal work arrangements are likely to earn less, to be uninsured, and to be in poverty.

\footnotetext{
${ }^{10}$ The 10 percent self-employment disadvantage is very similar to what we observe in data from the Survey of Income and Program Participation. Using a similarly defined sample of low-skilled non-citizen Hispanic men, we found an unadjusted mean difference in the log of annual earnings of about 9.5 percent. In an OLS regression including controls for factors such as age, experience, education, family composition, geographic location and previous year's labor market status, the self-employment disadvantage was slightly greater, about 14.8 percent.
} 


\section{Conclusions}

Using the synthetic control approach for assessing the impact of a single policy change in single area, we estimate the impact of the Legal Arizona Workers Act of 2007 on employment in Arizona. Evidence to-date implies that LAWA was largely successful in meeting its goal of deterring unauthorized immigration to the state and preventing employment of unauthorized workers. In previous work, we estimate a roughly 17 percent decline in unauthorized population of the state (Bohn, Lofstrom and Raphael 2010). In this paper, we find that for the unauthorized workers who chose to live in Arizona following LAWA, there were sizeable shifts in employment opportunities. LAWA caused a decline in the rate of formal employment by about 11 percentage points. This decline appears not to have had deleterious consequences - nor observable benefits - for competing workers.

However, the unintended consequence of the LAWA-induced declining employment opportunities for unauthorized workers was a doubling of the rate of self-employment for unauthorized, less-skilled men, from 8 to 16 percent.

While an increase in self-employment does not necessarily imply growth in the underground labor market, we find suggestive evidence that for unauthorized workers in Arizona the two are likely to go hand in hand. Our analysis and review of the literature suggests that selfemployment for low-skilled non-citizen Hispanic immigrants is associated with constricted earnings, increase in poverty, and a decrease in health insurance coverage.

Furthermore, to the extent that self-employment reflects less-formal work arrangements, there are potential deleterious consequences for the broader economy. The self-employed 
contribute less revenue through taxation. And the potential for worker exploitation is elevated in less formal work arrangements due to the lack of worker protections.

Although Arizona's E-Verify mandate achieved its goal of deterring unauthorized immigration and employment, it also generated unintended consequences on the labor market. The induced shift toward less formal work arrangements for unauthorized immigrants who continued to reside in the state after January 1, 2008 likely has negative implications on their economic well-being. Some of the affected workers are likely to migrate elsewhere for better labor market opportunities. However, for unauthorized immigrants unlikely to migrate due to family ties, for example, there are substantive and potentially long-term consequences on economic well-being. This could extend not just to unauthorized immigrants but also to their native-born children or relatives. Policymakers should into account both the intended and unintended consequences of similar E-Verify mandates. 


\section{References}

Abadie, Alberto; Diamond, Alexis and Jens Hainmueller (2010). "Synthetic Control Methods for Comparative Case Studies: Estimating the Effect of California’s Tobacco Control Program,” Journal of the American Statistical Association, 105(490): 493-505.

Arizona Attorney General (2010). Website: Arizona Employers Enrolled in E-Verify, http://www.azag.gov/LegalAZWorkersAct/EVerifyList.html, accessed March 2010.

Bernhardt, Annette, Siobhan McGrath, \& James DeFilippis (2007). “Unregulated Work in the Global City: Employment and Labor Law Violations in New York City”, Brennan Center for Justice Report.

Bohn, Sarah and Emily Owens (2010). “Immigration and Informal Labor”, PPIC Working Paper.

Bohn, Sarah, Magnus Lofstrom and Steven Raphael (2011). "Did the 2007 Legal Arizona Workers Act Reduce the State’s Unauthorized Immigrant Population?” IZA Working Paper No. 5682.

Buchmueller, Thomas C, DiNardo, John and Robert G. Valleta (2009). “The Effect of An Employer Health Insurance Mandate on Health Insurance Coverage and the Demand for Labor: Evidence from Hawaii,” Federal Reserve Bank of San Francisco Working Paper \#2009-08.

Congressional Budget Office (2008). Memo from Director Orzag to Committee on the Judiciary dated April 4, 2008.

De Soto, Hernando (1989). The Other Path. New York: Harper \& Row Publishers

Fairlie, Robert and Chrisopher Woodruff (2010). "Mexican-American Entrepreneurship”, Berkeley Electronic Press Journal of Economic Analysis \& Policy, Vol.10 : Issue. 1 (Contributions), Article 10.

Fairlie, Robert and Christopher Woodruff (2007). "Mexican Entrepreneurship: A Comparison of Self-Employment in Mexico and the United States” in Mexican Immigration, ed. George Borjas, Chicago: University of Chicago Press.

Feige, Edgar (1990). "Defining and Estimating Underground and Informal Economies: The New Institutional Economics Approach”, World Development 18(7): 989-1002.

Flaming, Daniel, Brent Haydamack, \& Pascale Joassart (2005). “Hopeful Workers, Marginal Jobs: LA’s Off-the Books Labor Force”, Economic Roundtable.

Gonzalez, Arturo (2007). "Day Labor in the Golden State”, Public Policy Institute of California, California Economic Policy 3(3). 
Hoefer, Michael, Nancy Rytina, and Bryan Baker (2010). Estimates of the Unauthorized Immigrant Population Residing in the United States: January 2009. Washington DC, Department of Homeland Security Office of Immigration Statistics.

Light, Ivan (2006). Deflecting Immigration: Networks, Markets and Regulation in Los Angeles. New York: Russell Sage Foundation.

Lofstrom, Magnus and Chunbei Wang (2009) "Mexican-American Self-Employment: A Dynamic Analysis of Business Ownership”, Research in Labor Economics, 2009, Vol. 29, pp.197-227.

Los Angeles Times (April 19,2010). Arizona has rarely invoked its last tough immigration law, by Nicole Santa Cruz.

Marcelli, Enrico A., Manuel Pastor, Jr., and Pascale M. Joassart (1999). "Estimating the Effects of Informal Economic Activity: Evidence from Los Angeles County”, Journal of Economic Issues 33(3): 579-607.

Meissner, D. and M. Rosenblum (2009). The Next Generation of E-Verify: Getting Employment Verificiation Right. Washington DC, Migration Policy Institute.

National Conference of State Legislatures (2006-2010). 2006-2010 State Legislation Related to Immigratns: Enacted and Vetoed. Washington DC.

Office of Immigration Statistics (2010). “2009 Yearbook of Immigration Statistics”, Department of Homeland Security.

Passel, Jeffrey and D'Vera Cohn (2010). U.S. Unauthorized Immigration Flows Are Down Sharply Since Mid-Decade. Washington DC, Pew Hispanic Center.

Passel, Jeffrey and D'Vera Cohn (2009a). A Portrait of Unauthorized Immigrants in the United States. Washington DC, Pew Hispanic Center.

Passel, Jeffrey and D'Vera Cohn (2009b). Mexican Immigrants: How Many Come? How Many leave? Washington DC, Pew Hispanic Center.

Rosenblum, M. (2009). The Basics of E-Verify, the US Employer Verification System. Washington DC, Migration Policy Institute.

Schneider, Friedrich \& Dominik Enste (2000). "Shadow Economies: Sizes, Causes, and Consequences” Journal of Economic Literature 38(1): 77-114.

Valenzuela, Abel, Nik Theodore, Edwin Melendez \& Ana Luz Gonzalez (2006). "On The Corner: Day Labor in the United States,” UCLA Center for the Study of Urban Poverty.

Westat (2007) Findings of the Web Basic Pilot Evaluation. Rockville, MD. 
Westat (2009). Findings of the E-Verify Program Evaluation. Rockville, MD 
Figure 1: Annual Employment Growth in Arizona and Bordering States, 1999-2009

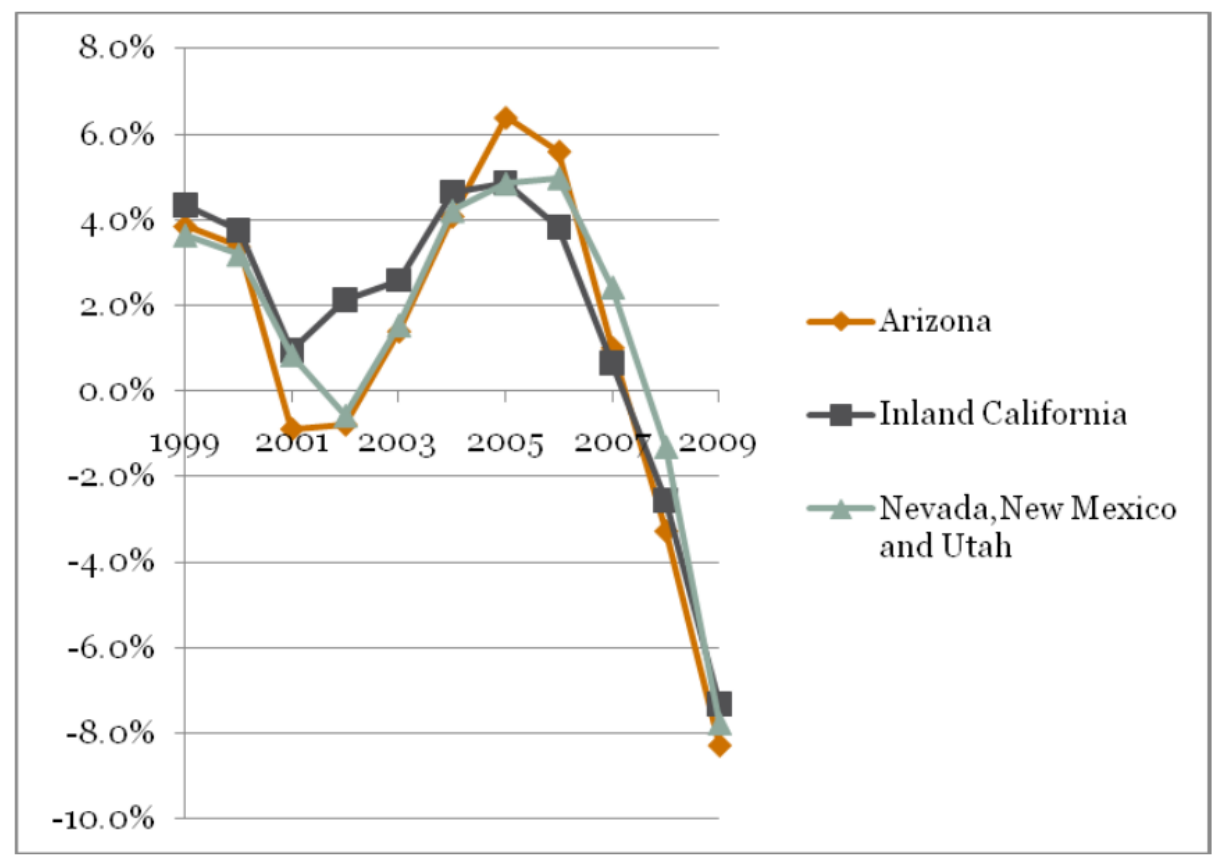

SOURCE: Author’s calculations from the 1998-2009 Quarterly Census of Employment and Wages (QCEW)

Figure 2: Annual Employment Growth in Construction in Arizona and Bordering States, 1999-2009

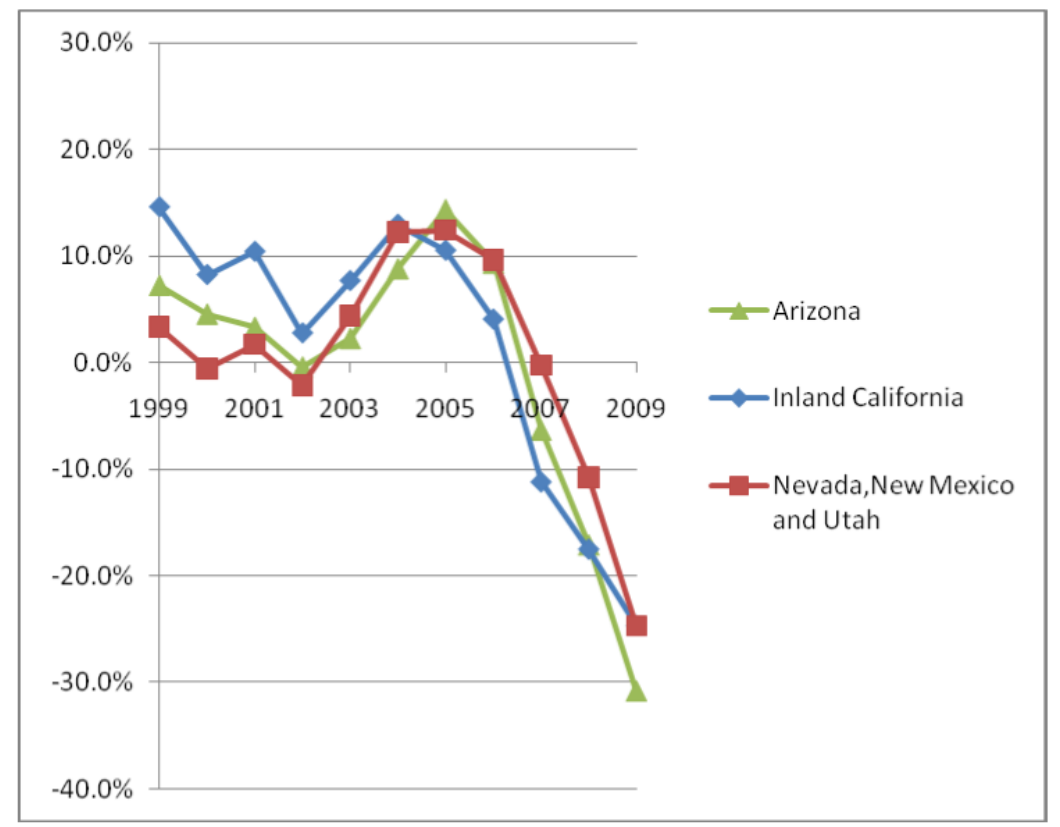

SOURCE: Author’s calculations from the 1998-2009 Quarterly Census of Employment and Wages (QCEW) 
Figure 3.

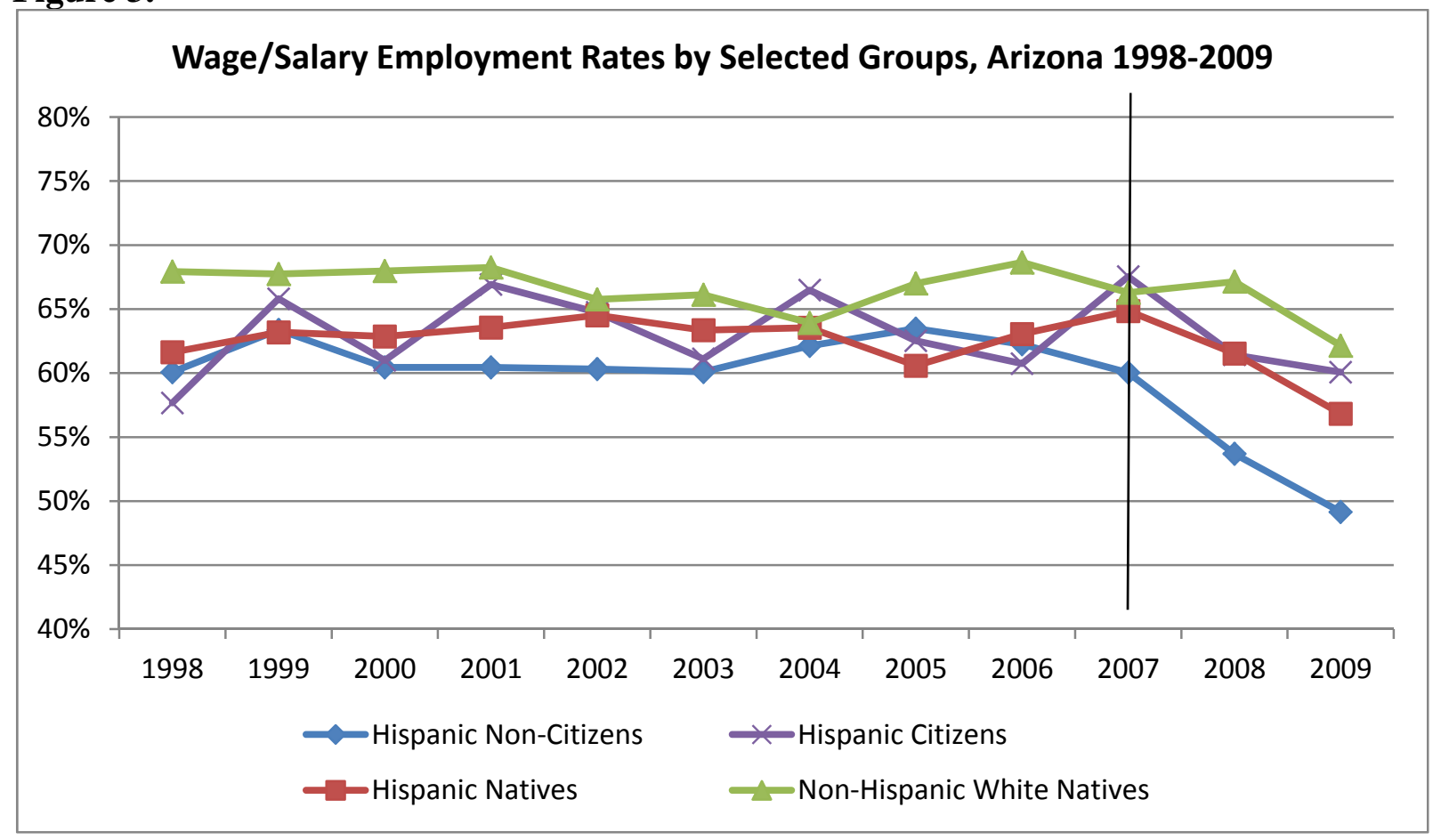

Figure 4.

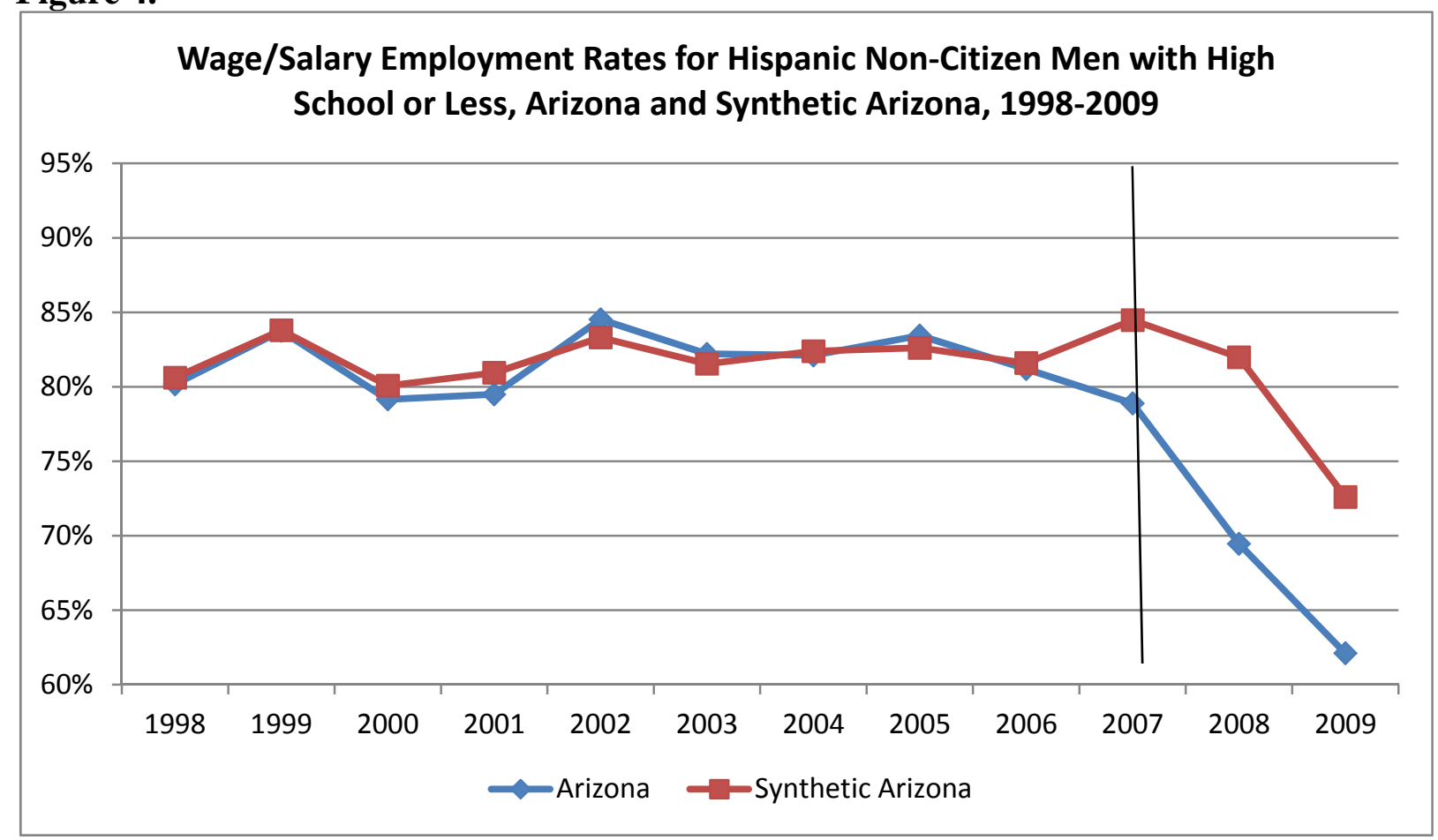

Notes: Synthetic Arizona consists of the following states (with weights in parentheses): California (0.845), New Mexico (0.077), Indiana (0.04), Nebraska (0 .024), District of Columbia (0.011) and Washington (0.003) 
Figure 5. Difference in Wage/Salary Employment Rates Relative to the Synthetic Control Group, Hispanic Non-Citizen Men with High School or Less, All States (Arizona Displayed with Thick Red Line).

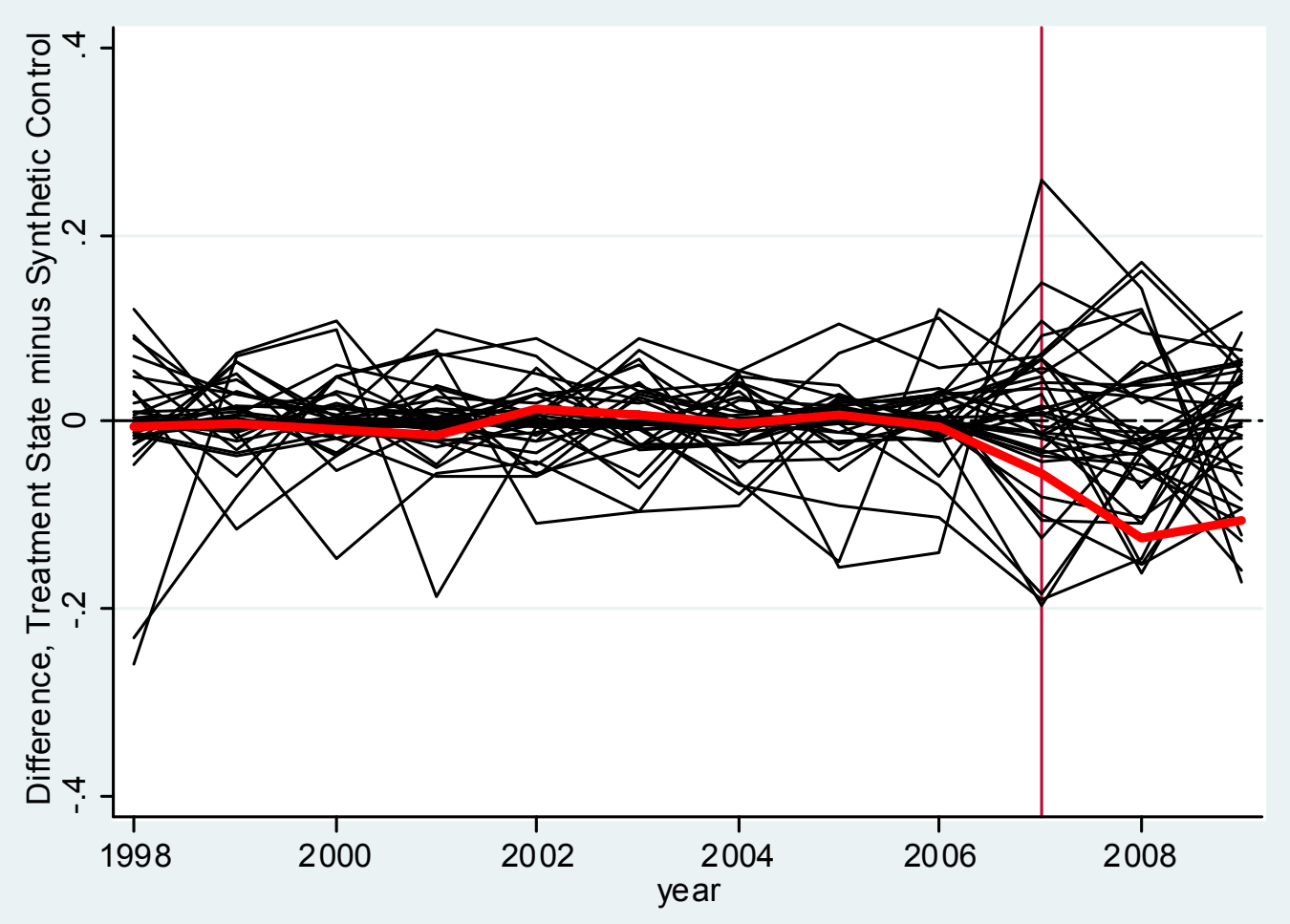

Figure 6.

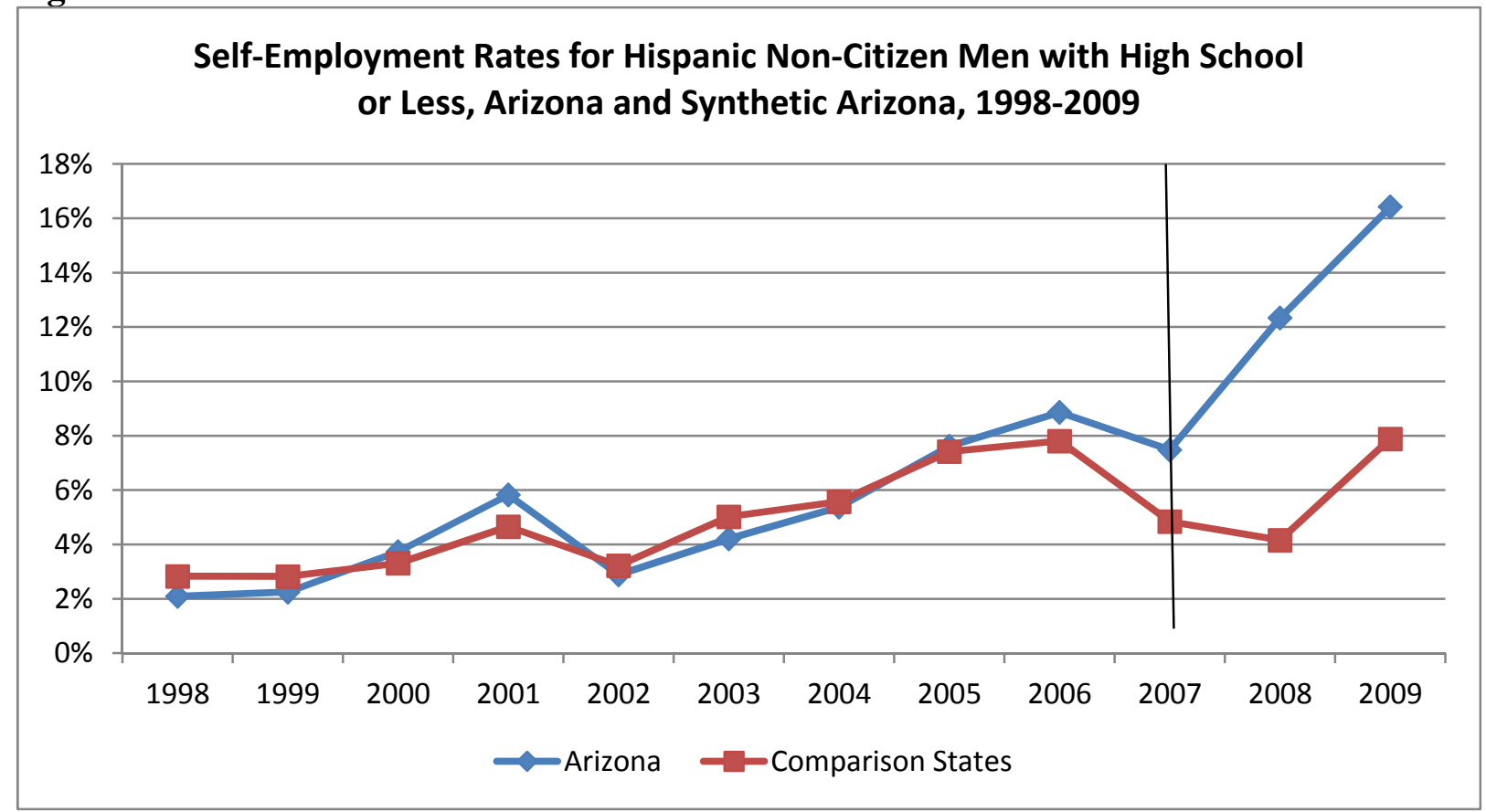

Notes: Synthetic Arizona consists of the following states (with weights in parentheses): Washington (0.32),

Massachusetts (0.243), Alaska (0.143), California (0.108), Iowa (0.082), Louisiana (0.076), Ohio (0.023) and Texas (0.005) 
Figure 7. Difference in Self-Employment Rates Relative to the Synthetic Control Group, Hispanic Non-Citizen Men with High School or Less, All States (Arizona Displayed with Thick Red Line).

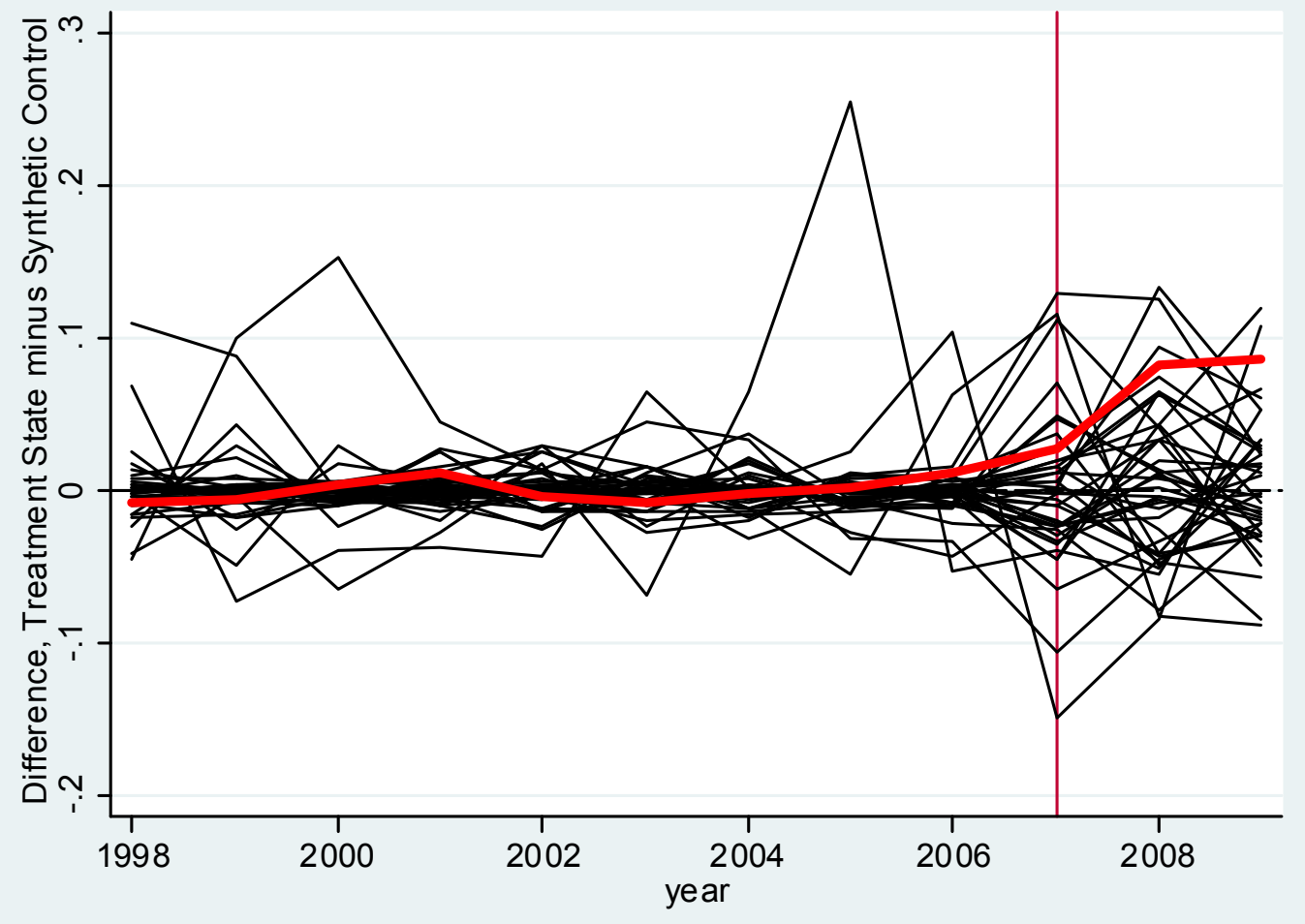


Table 1.

Estimated Impact of the Passage and Introduction of LAWA: Wage/Salary Employment

$\begin{array}{ccccc}\text { Pre-average } & \begin{array}{c}\text { Post-average } \\ \text { difference }\end{array} & \begin{array}{c}\text { Change, post } \\ \text { difference }\end{array} & \begin{array}{c}\text { Rank, } \\ \text { minus pre }\end{array} & \begin{array}{c}\text { P-value } \\ \text { difference- }\end{array} \\ \text { from one- } \\ \text { relative to } & \text { relative to } & \text { (Difference-in- } & \text { in- } & \text { tailed test, } \\ \text { synthetic } & \text { synthetic } & \text { difference } & \text { difference } & \mathrm{P}(|\Delta|<|\Delta A Z|) \\ \text { cohort } & \text { cohort } & \text { estimate) } & \text { estimate } & \end{array}$

\begin{tabular}{llllll}
\hline Panel A: Hispanic Non-Citizens & \multicolumn{5}{l}{} \\
\hline All & -0.0033 & -0.1081 & -0.1048 & $43 / 45$ & 0.067 \\
High School or Less & -0.0036 & -0.0660 & -0.0623 & $34 / 40$ & 0.175 \\
High School or Less, Men & -0.0009 & -0.1151 & -0.1142 & $40 / 40$ & 0.025 \\
High School or Less, Women & -0.0138 & -0.0294 & -0.0156 & $24 / 40$ & 0.425 \\
\hline Panel B: Hispanic Citizens & & & & \\
\hline All & -0.0061 & -0.0074 & -0.0013 & $22 / 44$ & 0.523 \\
High School or Less & -0.0104 & 0.0273 & 0.0377 & $21 / 35$ & 0.429 \\
High School or Less, Men & -0.0129 & -0.0755 & -0.0626 & $28 / 38$ & 0.289 \\
High School or Less, Women & -0.0042 & 0.0945 & 0.0987 & $22 / 35$ & 0.400 \\
\hline Panel C: Hispanic Natives & & & & & \\
\hline All & 0.0002 & 0.0229 & 0.0227 & $23 / 45$ & 0.511 \\
High School or Less & 0.0009 & 0.0513 & 0.0504 & $24 / 45$ & 0.489 \\
High School or Less, Men & -0.0001 & 0.0106 & 0.0107 & $23 / 45$ & 0.511 \\
High School or Less, Women & -0.0027 & 0.0054 & 0.0080 & $21 / 44$ & 0.455 \\
\hline Panel D: Non-Hispanic White Natives & & & & \\
\hline All & -0.0006 & -0.0032 & -0.0027 & $23 / 45$ & 0.511 \\
High School or Less & 0.0002 & -0.0154 & -0.0156 & $33 / 45$ & 0.289 \\
High School or Less, Men & 0.0022 & -0.0335 & -0.0357 & $37 / 45$ & 0.200 \\
High School or Less, Women & 0.0002 & 0.0142 & 0.0139 & $36 / 45$ & 0.222 \\
\hline Nos
\end{tabular}

Notes: Estimates based on 1998-2009 monthly Current Population Survey. 
Table 2.

Estimated Impact of the Passage and Introduction of LAWA: Self-Employment

\begin{tabular}{|c|c|c|c|c|}
\hline $\begin{array}{l}\text { De-average } \\
\text { difference } \\
\text { relative to } \\
\text { synthetic } \\
\text { cohort }\end{array}$ & $\begin{array}{l}\text { Post-average } \\
\text { difference } \\
\text { relative to } \\
\text { synthetic } \\
\text { cohort }\end{array}$ & $\begin{array}{l}\text { Change, post } \\
\text { minus pre } \\
\text { (Difference-in- } \\
\text { difference } \\
\text { estimate) }\end{array}$ & $\begin{array}{c}\text { Rank, } \\
\text { difference- } \\
\text { in- } \\
\text { difference } \\
\text { estimate }\end{array}$ & $\begin{array}{r}\mathrm{P}-1 \\
\text { fron } \\
\text { taile } \\
\mathrm{P}(|\Delta|\end{array}$ \\
\hline
\end{tabular}

\begin{tabular}{llllll}
\hline Panel A: Hispanic Non-Citizens & \multicolumn{5}{l}{} \\
\hline All & 0.0002 & 0.0423 & 0.0421 & $41 / 45$ & 0.111 \\
High School or Less & 0.0000 & 0.0305 & 0.0305 & $32 / 40$ & 0.225 \\
High School or Less, Men & 0.0002 & 0.0836 & 0.0834 & $39 / 40$ & 0.050 \\
High School or Less, Women & 0.0004 & 0.0012 & 0.0008 & $21 / 40$ & 0.500 \\
\hline Panel B: Hispanic Citizens & & & & \\
\hline All & 0.0002 & 0.0200 & 0.0198 & $34 / 44$ & 0.250 \\
High School or Less & 0.0005 & 0.0235 & 0.0230 & $22 / 35$ & 0.400 \\
High School or Less, Men & 0.0057 & 0.0849 & 0.0792 & $32 / 38$ & 0.184 \\
High School or Less, Women & -0.0001 & -0.0327 & -0.0326 & $23 / 35$ & 0.371 \\
\hline Panel C: Hispanic Natives & & & & & \\
\hline All & -0.0001 & -0.0072 & -0.0072 & $32 / 45$ & 0.311 \\
High School or Less & -0.0001 & -0.0094 & -0.0093 & $29 / 45$ & 0.378 \\
High School or Less, Men & 0.0001 & 0.0002 & 0.0001 & $25 / 45$ & 0.467 \\
High School or Less, Women & -0.0006 & -0.0088 & -0.0082 & $25 / 44$ & 0.477 \\
\hline Panel D: Non-Hispanic White Natives & & & & \\
\hline All & -0.0001 & -0.0075 & -0.0074 & $38 / 45$ & 0.178 \\
High School or Less & -0.0003 & -0.0117 & -0.0115 & $41 / 45$ & 0.111 \\
High School or Less, Men & -0.0009 & -0.0072 & -0.0063 & $34 / 45$ & 0.267 \\
High School or Less, Women & -0.0004 & -0.0067 & -0.0063 & $31 / 45$ & 0.333 \\
\hline Nos: Esing
\end{tabular}

Notes: Estimates based on 1998-2009 monthly Current Population Survey. 
Table 3

Sensitivity Analysis of Estimated Impact of the Passage and Introduction of LAWA: Non-Citizen Men with High School or Less

Pre-average
difference
relative to
synthetic
cohort

Post-average
difference
relative to
synthetic
cohort

Change, post

minus pre

Rank,

(Difference-in-

difference

difference-in-

P-value from

cohort

cohort

estimate)

\begin{tabular}{|c|c|c|c|c|c|}
\hline \multicolumn{6}{|l|}{ Panel A: Wage/Salary Employment } \\
\hline Exclude 2007 (Panel A, Table 1) & -0.0009 & -0.1151 & -0.1142 & $40 / 40$ & 0.025 \\
\hline Include 2007 as a pre-period & -0.0010 & -0.1032 & -0.1021 & $40 / 40$ & 0.025 \\
\hline Include 2007 as a post-period & -0.0009 & -0.0954 & -0.0944 & $38 / 40$ & 0.075 \\
\hline Excluding states bordering Arizona & -0.0009 & -0.1151 & -0.1142 & $37 / 37$ & 0.027 \\
\hline Falsification test, 2004 as treatment year & -0.0005 & 0.0311 & 0.0316 & $27 / 40$ & 0.350 \\
\hline
\end{tabular}

Estimates based on employment generated state weights, matched on sub-sample:

\begin{tabular}{|c|c|c|c|c|c|}
\hline Non-Citizen Hispanic Men with High School or Less ${ }^{\text {a) }}$ & -0.0136 & -0.1185 & -0.1049 & $\mathrm{~N} / \mathrm{A}$ & $\mathrm{N} / \mathrm{A}$ \\
\hline \multicolumn{6}{|l|}{ Panel B: Self-Employment } \\
\hline Exclude 2007 (Panel A, Table 1) & 0.0002 & 0.0836 & 0.0834 & $39 / 40$ & 0.050 \\
\hline Include 2007 as a pre-period & 0.0003 & 0.0796 & 0.0793 & $39 / 40$ & 0.050 \\
\hline Include 2007 as a post-period & 0.0011 & 0.0645 & 0.0634 & $38 / 40$ & 0.075 \\
\hline Excluding states bordering Arizona & 0.0002 & 0.0836 & 0.0834 & $36 / 37$ & 0.054 \\
\hline Falsification test, 2004 as treatment year & 0.0018 & 0.0435 & 0.0417 & $34 / 40$ & 0.175 \\
\hline
\end{tabular}

Estimates based on employment generated state weights, matched on sub-sample:

\begin{tabular}{|c|c|c|c|c|c|}
\hline Non-Citizen Hispanic Men with High School or Less ${ }^{\text {a) }}$ & 0.0108 & 0.0799 & 0.0691 & $\mathrm{~N} / t$ & N/A \\
\hline
\end{tabular}

Notes: Estimates based on 1998-2009 monthly Current Population Survey. a) States receiving non-zero weights (weight): California (0.771), New Mexico

(0.121), Washington (0.098), Louisiana (0.007) and Indiana (0.003) 
Table 4

Descriptive Statistics, Hispanic Non-Citizens Residing in Arizona Before and/or After LAWA.

\begin{tabular}{l|c|c|c|c}
\hline \multirow{2}{*}{ Group } & Pre-LAWA & \multicolumn{3}{|c}{ Post-LAWA } \\
\cline { 2 - 5 } & $\mathbf{2 0 0 5 - 2 0 0 6}$ & $\mathbf{2 0 0 8 - 2 0 0 9}$ & \multicolumn{2}{|c}{$\mathbf{2 0 0 9 - 2 0 1 0}$} \\
\hline Average: & AZ & AZ & AZ & Leavers \\
Age & 33.7 & 35.5 & 36.4 & 32.6 \\
High School Dropout & 0.50 & 0.52 & 0.49 & 0.48 \\
High school or less & 0.85 & 0.84 & 0.82 & 0.84 \\
Female & 0.43 & 0.44 & 0.46 & 0.41 \\
Married & 0.58 & 0.53 & 0.55 & 0.54 \\
Born in Mexico & 0.94 & 0.94 & 0.93 & 0.92 \\
Recent Immigrant (<10 Years) & 0.57 & 0.45 & 0.39 & 0.41 \\
Limited English Proficiency & 0.64 & 0.60 & 0.57 & 0.42 \\
Employed & 0.67 & 0.62 & 0.58 & 0.44 \\
Unemployed & 0.07 & 0.10 & 0.14 & 0.22 \\
Self-Employed & 0.07 & 0.09 & 0.09 & 0.02 \\
For Employed Persons, Median: & & & & \\
$\quad$ Total Personal Income & 18,000 & 20,000 & 19,200 & 20,000 \\
Income from Wage and Salary & 17,000 & 18,300 & 18,000 & 20,000 \\
Total Family Income & 31,200 & 34,000 & 30,900 & 25,000 \\
N & & & & \\
N & 6,353 & 6,001 & 5,839 & 136 \\
\hline
\end{tabular}

Notes: Based on 2005-2010 American Community Survey. Restricted to age 16-65. Leavers are defined by current residence in any state other than Arizona and reporting lived in Arizona 1 year before survey. All other columns include all Hispanic non-citizens in Arizona. 


\section{Table 5}

Industrial and Occupational Distributions, Low-Skilled Self-Employed Hispanic Non-Citizen Men, 2008-2009.

\begin{tabular}{lclc}
\hline Top 15 Industries & $\%$ & Top 15 Occupations & $\%$ \\
\hline Construction & 46.6 & Grounds Maintenance Workers & 14.8 \\
Landscaping services & 17.7 & Construction Laborers & 14.2 \\
Automotive repair and maintenance & 4.9 & Carpenters & 7.4 \\
Truck transportation & 3.7 & Painters, Construction and Maintenance & 6.5 \\
Restaurants and other food services & 3.1 & Driver/Sales Workers and Truck Drivers & 4.6 \\
Building services & 2.5 & Automotive Service Technicians and Mechanics & 3.3 \\
Private households, services & 1.5 & Supervisors/Managers, Construction & 2.6 \\
Crop production & 1.1 & Supervisors/Managers, Landscaping & 2.6 \\
Taxi and limousine service & 0.9 & Carpet, Floor, and Tile Installers and Finishers & 2.3 \\
Independent artists \& performing arts & 0.9 & Managers, All Other & 2.1 \\
Grocery stores & 0.8 & Constructions Managers & 2.1 \\
Automobile dealers & 0.7 & Supervisors/Managers, Retail Sales & 2.1 \\
Other direct selling establishments & 0.7 & Retail Salespersons & 2.1 \\
Car washes & 0.7 & Drywall and Ceiling Tile Installers and Tapers & 2.0 \\
Recyclable material, merchant wholesalers & 0.7 & Roofers & 1.9 \\
All other industries & 13.8 & All other occupations & 29.6 \\
\hline
\end{tabular}

Notes: Based on 2008-2009 American Community Survey. 
Table 6

Descriptive Statistics, Hispanic Men, High School or Less, 2008-2009

\begin{tabular}{|c|c|c|c|c|}
\hline & \multicolumn{2}{|c|}{ Hispanic Non-Citizens } & \multicolumn{2}{|c|}{ Naturalized Hispanics } \\
\hline & Self-Employed & Wage/Salary & Self-Employed & Wage/Salary \\
\hline Age & 38.4 & 35.5 & 46.8 & 44.2 \\
\hline Years in the US & 15.5 & 13.2 & 26.5 & 24.9 \\
\hline High School Graduate & 0.30 & 0.31 & 0.43 & 0.45 \\
\hline Limited English Proficiency & 0.82 & 0.84 & 0.61 & 0.63 \\
\hline Married & 0.62 & 0.55 & 0.81 & 0.75 \\
\hline Family Size & 3.77 & 3.69 & 3.87 & 3.96 \\
\hline Number of Children & 1.30 & 1.02 & 1.57 & 1.44 \\
\hline Number of Children Younger than 5 & 0.28 & 0.27 & 0.19 & 0.20 \\
\hline Usual Hours Work per Week & 39.56 & 40.67 & 43.06 & 41.73 \\
\hline \multicolumn{5}{|l|}{ Mean } \\
\hline Total Personal Income & 26,000 & 23,700 & 41,400 & 35,500 \\
\hline Total Personal Earnings & 25,600 & 23,500 & 39,700 & 34,500 \\
\hline Total Family Income & 44,600 & 43,400 & 65,600 & 61,200 \\
\hline Total Household Income & 52,700 & 55,200 & 69,900 & 66,300 \\
\hline \multicolumn{5}{|l|}{ Median } \\
\hline Total Personal Income & 18,000 & 20,000 & 30,000 & 30,000 \\
\hline Total Personal Earnings & 18,000 & 20,000 & 28,800 & 30,000 \\
\hline Total Family Income & 30,000 & 34,400 & 50,000 & 52,200 \\
\hline Total Household Income & 39,000 & 46,000 & 54,400 & 57,100 \\
\hline Income Percent of Poverty Threshold & 193 & 205 & 266 & 273 \\
\hline Below Poverty Threshold & 0.27 & 0.18 & 0.12 & 0.07 \\
\hline Any Health Insurance & 0.18 & 0.32 & 0.43 & 0.70 \\
\hline Private Health Insurance & 0.12 & 0.28 & 0.33 & 0.64 \\
\hline Public Health Insurance & 0.06 & 0.05 & 0.12 & 0.09 \\
\hline Number of Observations & 5,466 & 51,946 & 2,150 & 14,929 \\
\hline
\end{tabular}

Notes: Based on 2008-2009 American Community Survey. 